\title{
Telaah Kritis Pasal 7 Undang-Undang No.16 Tahun 2019 Tentang Perkawinan
}

\author{
Elfirda Ade Putri \\ Fakultas Hukum, Universitas Bhayangkara Jakarta Raya \\ Email: elfirdade.putri@gmail.com
}

Received : 17 Sep 2021 | Revised : 26 Oct 2021 | Accepted : 22 Nop 2021 | Published : 9 Dec 2021

\begin{abstract}
Marriage is also regulated in Article 28B Paragraph 1 of the 1945 Constitution which states "Everyone has the right to form a family and continue their descendants through legal marriage". In Article 26 of the Civil Code, views the matter of marriage only in civil relations. This means that the law recognizes civil marriages as legal marriages, i.e. marriages that meet religious requirements or provisions are not given much attention or neglected. Meanwhile, according to the Compilation of Islamic Law Article 2 states that marriage is a marriage, a very strong contract or Miitsaaqan Gholiidhzan which aims to obey Allah's commands and carry out a worship. Based on statistical data and studies that have been done, early marriage is still a social problem in Indonesia. BAPPENAS data shows $34.5 \%$ of Indonesian children marry early. This data is corroborated by the PLAN International study which showed $33.5 \%$ of children aged $13 \pm 18$ years were married at the age of $15-16$ years. Early marriage inhibits the growth and development of children, both biologically and psychologically. Early marriage has an impact on the deprivation of children's rights because they are forced to enter the adult world instantly. Early marriage in Indonesia is motivated by many factors, such as the low level of the family's economy, low education, lack of knowledge and education and the most prevalent is pregnancy out of wedlock.
\end{abstract}

Keywords: critical studi, marriage

\begin{abstract}
ABSTRAK
Perkawinan juga diatur dalam Pasal 28B Ayat 1 UUD 1945 menyatakan "Setiap orang berhak membentuk keluarga dan melanjutkan keturunan melalui perkawinan sah". Dalam Pasal 26 KUHPerdata, memandang soal perkawinan hanya dalam hubungan-hubungan perdata saja. Hal ini berarti bahwa Undang-undangnya mengakui perkawinan perdata ialah perkawinan yang sah, yaitu perkawinan yang memenuhi syarat-syarat atau ketentuan agama tidak terlalu diperhatikan ataupun disampingkan. Sedangkan, menurut Kompilasi Hukum Islam Pasal 2 menyatakan perkawinan ialah sebuah pernikahan, akad yang sangat kuat atau Miitsaaqan Gholiidhzan yang bertujuan untuk menaati perintah Allah dan menjalankan suatu ibadah. Berdasarkan data statistik dan kajian yang pernah dilakukan, pernikahan dini masih menjadi persoalan sosial di Indonesia. Data BAPPENAS menunjukkan 34.5\% anak Indonesia menikah dini. Data ini dikuatkan dengan penelitian PLAN International yang menunjukkan 33,5\% anak usia $13 \pm 18$ tahun menikah pada usia 15-16 tahun. Pernikahan dini menghambat pertumbuhan dan perkembangan anak, baik secara biologis maupun psikologis. Pernikahan dini berdampak pada tercerabutnya hak anak-anak karena ia dipaksa memasuki dunia dewasa secara instan.
\end{abstract}


Perkawinan usia dini di Indonesia dilatarbelakangi oleh banyak faktor, seperti rendahnya tingkat ekonomi keluarga, rendahnya pendidikan, kurangnya pengetahuan dan edukasi serta yang paling marak yaitu kehamilan di luar nikah.

Kata Kunci: telaah kritis, perkawinan

\section{PENDAHULUAN}

Perkawinan menurut UU No. 1 Tahun 1974 ialah ikatan lahir bathin antara seorang pria dengan seorang wanita sebagai suami isteri dengan tujuan membentuk rumah tangga (rumah tangga) yang bahagia dan kekal berdasarkan berdasarkan ketuhanan yang maha esa. Menurut Undang-undang No. 1 Tahun 1974 kematangan usia perkawinan diukur berdasarkan kematangan jiwa dan raga yaitu dikatakan telah matang jiwa dan raganya untuk melakukan perkawinan ketika telah berusia 21 tahun ${ }^{1}$. Ketentuan ini terdapat di dalam Bab II pasal 7 ayat (1) yang menyebutkan bahwasanya perkawinan hanya diizinkan jika pihak pria sudah mencapai umur 19 tahun dan pihak wanita sudah mencapai umur 16 tahun. Perkawinan menurut KHI (Kompilasi Hukum Islam) adalah akad yang sangat kuat miitsaaqan gholidon untuk mematuhi perintah allah dan melaksanakannya merupakan ibadah. Perkawinan ini dinyatakan adalah sah apabila dilakukan menurut masing-masing agamanya dan kepercayaannya itu.

Perkawinan menurut uu no 16 tahun 2019 perubahan atas uu no 1 tahun 1974 ialah Perkawinan hanya diizinkan apabila pria dan wanita sudah mencapai umur 19 (sembilan belas) tahun pada pasal 7 ayat $(1)^{2}$. Perkawinan adalah salah satu budaya yang beraturan yang mengikuti perkembangan budaya manusia dalam kehidupan masyarakat. Dalam masyarakat sederhana budaya perkawinannya sederhana, sempit, dan tertutup, dalam masyarakat yang maju (modern) budaya perkawinannya maju, luas dan terbuka. ${ }^{3}$

Budaya perkawinan dan aturannya yang berlaku pada suatu masyarakat atau padasuatu bangsa tidak terlepas dari pengaruh budaya dan lingkungan di mana masyarakat itu berada serta pergaulan masyarakatnya. ${ }^{4}$ Didalam pasal 1 uu no 1 tahun 1974 di katakan bahwa :perkawinan ialah ikatan lahir batin antara seorang pria dengan seorang wanita sebagai suami isteri dengan tujuan membentuk keluarga (rumah tangga) yang bahagia dan kekal berdasarkan ketuhanan yang maha esa. Perkawinan menurut perundangan ialah ikatan antara seorang pria dengan seorang wanita, berarti perkawinan sama dengan perikatan (verbindtenis). ${ }^{5}$

UU no 1 tahun 1974 tentang perkawinan menganut asas-asas atau prinsipprinsip sebagai berikut :

a) Perkawinan bertujuan membentuk keluarga bahagia dan kekal

b) Perkawinan adalah sah bilamana dilakukan menurut hukum agamanya dan kepercayaannya itu

\footnotetext{
${ }^{1}$ UU No.1 Tahun 1974 Tentang Perkawinan

${ }^{2}$ UU No.16 Tahun 2019 Tentang Perkawinan (Perubahan atas UU No.1 Tahun 1974)

${ }^{3}$ Eleanora, F. N., \& Dwi Atmoko. (2021). Aktualisasi Sertifikasi Pranikah Dalam Meminimalisir Kekerasan Dalam Rumah Tangga. Jurnal Hukum Sasana, 7(1). https://doi.org/10.31599/sasana.v7i1.477

${ }^{4}$ Prof.H.Hilman Hadikusuma, "Hukum Perkawinan Indonesia”(Bandung:Mandar Maju) 2007. Hal. 1

5 Ibid hal 6
} 
c) Perkawinan harus di catat menurut peraturan perundang-undangan

d) Perkawinan berasas monogami terbuka

e) Calon suami isteri harus sudah masuk jiwaraganya untuk melangsungkan perkawinan

f) Batas umur perkawinan adalah bagi pria 19 tahun dan bagi Wanita 16 tahun

g) Perceraian dipersulit dan harus dilakuan dimuka sidang pengadilan

h) Hak dan kedudukan suami isteri seimbang ${ }^{6}$.

Tujuan perkawinan menurut uu no 1 tahun 1974 adalah untuk membentuk keluarga (rumah tangga) yang bahagia kekal berdasarkan Ketuhanan Yang Maha Esa. Dan selanjutnya bahwa untuk itu suami isteri perlu saling membantu dan melengkapi agar masing-masing dapat mengembangkan kepribadiannya membantu dan mencapai kesejahteraan spiritual dan material. ${ }^{7}$

Tujuan Perkawinan bagi masyarakat hukum adat yang bersifat kekerabatan adalah untuk mempertahankan dan meneruskan keturunan menurut garis kebapakan atau keibuan ntuk kebahagiaan rumah tangga/kerabat, untuk memperoleh nilai-nilai adat budaya dan kedamaian, dan untuk mempertahankan kewarisan. ${ }^{8}$ Tujuan perkawinan menurut Hukum Islam untuk menegakkan agama, untuk mendapatkan keturunan, untuk mencegah maksiat dan untuk membina keluarga rumah tangga yang damai dan teratur. ${ }^{9}$

Pada tahun 2014, berbagai koalisi lembaga sosial dan masyarakat sipil yang yang bergerak di bidang perlindungan perempuan dan anak mengajukan permohonan pengujian ketentuan batas usia perkawinan dalam Undang-Undang Nomor 1 Tahun 1974 tentang Perkawinan terhadap Undang-Undang Dasar Tahun 1945. Meskipun demikian, permohonan ini ditolak oleh Mahkamah Konstitusi melalui Putusan Nomor 30-74/PUU-XII/2014. Dalam pertimbangan hukumnya, Mahkamah Konstitusi menyatakan bahwa batasan usia minimum merupakan kebijakan hukum terbuka (open legal policy). Menurut majelis hakim batas usia minimal perkawinan dapat diubah oleh lembaga legislatif sesuai dengan perkembangan zaman. Pembatasan usia perkawinan pada asasnya tidak dilarang dan selama tidak bertentangan dengan UUD 1945. Selain itu, tidak ada jaminan yang dapat memastikan bahwa dengan ditingkatkannya batas usia kawin untuk wanita dari 16 (enam belas) tahun menjadi 18 (delapan belas) tahun, akan mengurangi angka perceraian, menanggulangi permasalahan kesehatan, maupun meminimalisir permasalahan sosial lainnya ${ }^{10}$.

Berdasarkan data statistik dan kajian yang pernah dilakukan, pernikahan dini masih menjadi persoalan sosial di Indonesia. Data BAPPENAS menunjukkan 34.5\% anak Indonesia menikah dini. Data ini dikuatkan dengan penelitian PLAN International yang menunjukkan 33,5\% anak usia $13 \pm 18$ tahun menikah pada usia 15-16 tahun ${ }^{11}$. Pernikahan dini menghambat pertumbuhan dan perkembangan anak, baik secara biologis maupun psikologis. Pernikahan dini berdampak pada tercerabutnya hak anak-anak karena ia dipaksa memasuki dunia dewasa secara instan.

\footnotetext{
${ }^{6}$ Ibid. hal.6

7 Adi Nur Rohman. (2020). Upaya Memantapkan Peraturan Isbat Nikah Dalam Hukum Perkawinan Di Indonesia. Jurnal Hukum Sasana, 6(1). https://doi.org/10.31599/sasana.v6i1.173

${ }^{8}$ Masri, E. (2019). Poligami Dalam Perspektif Undang-Undang Nomor I Tahun 1974 Tentang Perkawinan Dan Kompilasi Hukum Islam (KHI). Krtha Bhayangkara, 13(2). https://doi.org/10.31599/krtha.v13i2.7

${ }^{9}$ Ibid. hal 21-23

${ }^{10}$ Putusan Mahkamah Konstitusi Nomor: 30-74/PUU-XII/2014.
11 Mayadina Rohmi Musfiroh,"Pernikahan Dini dan Upaya Perlindungan Anak di Indonesia"Jurnal.
} 
Perkawinan usia dini di Indonesia dilatarbelakangi oleh banyak faktor, seperti rendahnya tingkat ekonomi keluarga, rendahnya pendidikan, kurangnya pengetahuan dan edukasi serta yang paling marak yaitu kehamilan di luar nikah. ${ }^{12}$

Kehidupan berumah tangga melalui pernikahan merupakan salah satu lembaran hidup yang akan dilalui oleh setiap manusia. Saat itulah kedewasaan pasangan suami istri sangat dituntut demi mencapai kesuksesan dalam membina bahtera rumah tangga ${ }^{13}$ Wilayah Babelan merupakan daerah terpencil di pedalaman Bekasi. Yang memungkinkan masih maraknya pernikahan dini yang dilakukan oleh masyarakat disekitarnya. Dalam hal ini saya selaku peneliti telah melakukan penelitian di daerah babelan dan berkesempatan untuk mewawancara salah satu masyarakat yang melakukan pernikahan dini. Dan berdasarkan hasil wawancara, pernikahan dini ini dilakukan karena ketidakpahaman atas batas minimum menikah dan syarat menikah sesuai dengan peraturan perundang-undang no 16 Tahun 2019 terdapat di pasal 7 bahwa batas usia pernikahan perempuan dan laki laki adalah 19 tahun. Dan berdasarkan data dari kelurahan di wilayah Babelan yang diberikan oleh salah satu staff kelurahan yang bernama Ibu Een Suhaemi, Dan saya mendapatkan data permohonan menikah pada tahun 2019 sebanyak 697 pemohon dan tahun 2020 sebanyak 564 Pemohon.

Bahwa batas usia perkawinan yang ada dalam peraturan Perundang-Undangan Nomor 1 Tahun 1974 Pasal 7 Ayat 1 disebutkan "Perkawinan hanya diizinkan jika pihak pria sudah mencapai umur 19 (Sembilan belas) tahun dan pihak wanita sudah mencapai umur 16 (enam belas) tahun". dan terdapat pmbaharuan undangundang perkawinan nomor 16 tahun 2019 terjadi revisi di pasal 7 yang berisi Perkawinan hanya diizinkan apabila pria dan wanita sudah mencapai umur 19 (sembilan belas) tahun.

Tetapi faktanya pada masyarakat Kecamatan Babelan Kabupaten Bekasi, praktek perkawinan dibawah umur sering terjadi. Mereka melakukan perkawinan dengan menempuh cara memalsukan identitas KTP (Kartu Tanda Penduduk) dengan menambah umur yang sebenarnya belum mencapai usia yang dibenarkan oleh Undang-undang. Ada juga mereka yang tidak memperdulikan apa yang diatur oleh perundang-undangan. Yang mereka tahu, mereka mensyahkan perkawinannya tidak mesti di KUA (Kantor Urusan Agama) tetapi mereka melakukan perkawinan itu di Kyai atau Ustad-Ustad yang terpenting mereka menikah.

Di daerah tersebut perkawinan dibawah umur merupakan suatu hal yang lumrah dikarenakan adanya kekurang pahaman akan Undang-undang tersebut serta kebiasaan masyarakat di sana yang menikahkan anaknya setelah usia baligh. Suami isteri yang telah matang baik fisik maupun psikis tentu akan mampu mengatasi berbagai problema yang akan menerpa kehidupan rumah tangga mereka. Pastilah mereka akan sangat mudah goyah dan pada akhirnya rumah tangga mereka akan kandas di tengah perjalanan. Keluarga sakinah yang diidam-idamankan hanyalah sebuah utopia yang tidak mungkin diraih ${ }^{14}$. Dan merujuk pada data penelitian yang peneliti dapatkan, peneliti berhasil mewawancarai salah satu masyarakat yang

12 Muhammad Faisal Hendriawan, Putri, E. A., \& Otih Handayani. (2020). Analisis Legal Standing Penerbitan Surat Keterangan Nikah oleh Kepala Desa Pada Pernikahan Siri di Desa Banjarsari Bekasi. KRTHA BHAYANGKARA, 14(2). https://doi.org/10.31599/krtha.v14i2.389

${ }^{13}$ Agus Riyadi, Bimbingan Konseling Perkawinan,(Yogyakarta: Ombak, 2013), h. 150.

${ }^{14}$ Ashad Kusuma Djaya. "Rekayasa Sosial Lewat Malam Pertama : PesanPesan Rasulullah SAW Menuju Pernikahan Barakah”. (Yogyakarta : Kreasi Wacana 2000). Cet ke-2. h., 73. 
melakukan pernikahan dibawah umur, dan hal tersebut mereka lakukan karena tidak adanya kesadaran akan batas usia pernikahan, dan mereka menikah karena "Married by accident". Berdasarkan dari data tersebut, penulis tertarik dengan judul ini karena di wilayah Babelan banyak yang melakukan pernikahan di bawah umur.

Berdasarkan hal tersebut, maka dirumuskan permasalahan sebagai berikut : 1) Bagaimana Implementasi UU No. 16 Tahun 2019 Tentang Perubahan Atas UU No. 1 Tahun 1974 di Kabupaten Bekasi sudah sesuai dengan penempaanya? 2) Bagaimana upaya pencegahan dan perlindungan anak dibawah umur yang dilakukan secara nikah siri di sekitar Kabupaten Bekasi?

\section{PEMBAHASAN}

\section{A. Pengertian Perkawinan dibawah umur}

Perkawinan adalah sesuatu yang sakral dan suci dan siapapun berharap bahwa perkawinannya akan bahagia dan kekal selamanya dalam menjalankan rumah tangganya, namun jika dikaitkan dengan perkawinan di bawah umur yang banyak terjadi pada masyarakat pedesaan di Indonesia, hal ini dikarenakan tingkat pendidikan masyarakat pedesaan masih rendah dan belum memadai. Jadi tidak heran jika sebagian besar masyarakatnya masih berpegang teguh pada tradisi kuno terutama orang tuanya yang ingin secepatnya mengawinkan anak perempuannya dengan alasan ingin cepat punya cucu, selain dari pada itu orang tua akan merasa malu kalau anak perempuannya tidak kawin muda yang nantinya menimbulkan aib dalam keluarganya. ${ }^{15}$

Selain itu adanya anggapan sebagian orang bahwa dengan menikahkan anak maka tanggungjawab orangtua selesai dan menjadi tanggungjawab suaminya atau bertanggungjawab pada diri sendiri, apalagi kalau memiliki anak perempuan yang cantik oleh orang tuanya dieksploitasi dalam perkawinan, dikarenakan kondisi ekonomi dan terjerat hutang sering membuka adanya eksploitasi terhadap anak, terjadinya perdagangan anak dengan tujuan menikahkan anaknya maka hutangnya dianggap lunas atau tidak ada sama sekali. ${ }^{16}$

Perkawinan anak usia dini akan sangat mempengaruhi perkembangan fisik maupun psikologi. Anak yang melakukan perkawinan pada usia muda organ reproduksinya belum berfungsi secara optimal. Selain itu anak yang menikah pada usia muda belum siap untuk menjadi seorang ibu dalam arti kemampuan mengasuh anak serta dalam pengendalian emosi dan tindakannya. ${ }^{17}$ Menurut Hukum Islam Perkawinan di Bawah Umur dilakukan melewati batas minimal Undang-undang Perkawinan, secara Hukum positif perkawinan tersebut tidak sah. Atau bisa disimpulkan perkawinan menurut Hukum Islam adalah perkawinan yang dilakukan oleh pasangan yang belum Baligh.

Dari segi Psikologi, Sosiologi maupun Hukum Islam perkawinan dibawah umur terbagi menjadi dua bagian, yang pertama perkawinan dibawah umur asli, yaitu perkawinan di bawah umur yang benar-benar dilaksanakan oleh kedua belah pihak untuk menghindarkan diri dari dosa tanpa adanya maksud semata-mata hanya untuk menutupi perbuatan zina yang telah dilakukan oleh kedua mempelai, sedangkan yang kedua perkawinan dibawah umur palsu, yang dimaksudkan sebagai kamuflase dari

${ }^{15}$ Baharuddin Ahmad, “Hukum Perkawinan Di Indonesia, Studi Historis Metodologis”, (Jakarta : Balai Pustaka Februari 2008), halaman 57-58.

${ }^{16} \mathrm{Ibid}$, hlm 76

17 Ade Lanuari Abdan Syakuro, "Perkawinan Dibawah Umur", (http://www.gotzlanade./2014/02/perkawinan-dibawah-umur.html?m=1), diakses 25 februari 2021, pukul 13.30 
kebejatan perilaku kedua mempelai, perkawinan ini hanya untuk menutupi perbuatan zina yang pernah dilakukan oleh keduanya. ${ }^{18}$

Perkawinan usia muda atau perkawinan di bawah umur biasanya bermula dari ketahuannya kerja sama antara petugas pegawai pencatat nikah dengan para orang tua calon pasangan yang memanipulasi umur, bila terjadi masalah dalam rumah tangga pasangan tersebut yang berujung pada perceraian di pengadilan setempat, ternyata diketahui bahwa pasangan tersebut belum cukup umur untuk menikah. Sedangkan menurut Undang-undang negara kita telah menganut batasan usia perkawinan. Kebijakan pemerintah dalam menetapkan batasan minimal usia perkawinan ini tentunya melalui proses dan berbagai pertimbangan. Hal ini dimaksudkan agar kedua belah pihak benar-benar siap dan matang dari sisi fisik, psikis dan mental ${ }^{19}$

\section{B. Batasan umum melakukan perkawinan}

\section{Batasan umum melakukan perkawinan menurut Fiqh Islam}

Tidak adanya ketentuan Fiqh tentang batas usia minimal dan maksimal untuk menikah, kiranya sesuai dengan pandangan umat ketika itu tentang hakikat perkawinan. Menurut mereka perkawinan itu tidak dilihat dari segi hubungan kelamin saja, tetapi dari segi pengaruhnya dalam menciptakan hubungan kekeluargaan. Dalam salah satu definisi perkawinan disebutkan bahwa perkawinan itu akan menimbulkan hak dan kewajiban timbal balik antara suami dan istri, Adanya hak dan kewajiban atas suami dan istri mengandung arti bahwa pemegang tanggung jawab dan hak kewajiban itu sudah dewasa, memiliki kemampuan bertindak hukum secara sempurna. Sehingga perkawinan harus dilakukan oleh orang yang sudah dewasa (baligh). ${ }^{20}$

Tanda-tanda kedewasaan (baligh) untuk laki-laki antara lain:

1. Ihtilam, yaitu keluarnya mani karena mimpi.

2. Tumbuhnya rambut kemaluan merupakan tanda baligh secara mutlak, baik menyangkut hak Allah atau hak anak Adam.

3. Mencapai usia tertentu, Para ulama berbeda pendapat mengenai hal ini, Menurut ulama madzhab hanafiyah anak laki-laki yang belum berusia delapan belas tahun belum bisa dikatakan baligh.

Sedangkan menurut mereka pertumbuhan anak perempuan bisa dikatakan dewasa ketika sudah mencapai tujuh belas tahun. Mereka beralasan bahwa ketentuan dewasa menurut syara' adalah ihtilam (mimpi basah) dan menurut mereka ihtilam tidak diharapkan lagi datangnya jika umur sudah mencapai delapan belas tahun dan karena itu mereka menetapkan bahwa usia dewasa itu setelah umur delapan belas tahun. Ulama Syafi'iah menentukan bahwa masa dewasa itu mulai umur 15 tahun. ${ }^{21}$

Tetapi ketika umur belum sampai 15 tahun anak laki-laki ataupun perempuan sudah ihtilam, maka sudah dikatakan dewasa. Disamakannya masa kedewasaan untuk pria dan wanita adalah karena kedewasaan itu ditentukan dengan akal. Dengan akallah

${ }_{19}^{18}$ Ibid, Ade Lanuari Abdan Syakuro

19 Nurul "Praktek Perkawinan Dini", (http://muhammadsarito.blogspot.com/2014/11/praktekpernikahan-dini-di-pedesaan.html), diakses 25 februari 2021, pukul 13.34 Wib

20 Muhammad Baqir al-Habsyi, fiqh Praktis (Seputar Perkawinan dan Warisan), Mizan, Bandung, 2003, hlm.56.

${ }^{21}$ Ibid,hlm 71 
terjadi taklif, dan karena akal pulalah adanya hukum. Adapun tanda-tanda baligh anak perempuan bisa seperti laki-laki, namun ditambah dengan keempatnya, yaitu haidh, berkembangnya alatalat untuk berketurunan, serta membesarnya buah dada. Para ulama telah sepakat bahwa haidh merupakan tanda baligh bagi seorang wanita. menurut Fiqh tidak disebutkan secara jelas batasan usia untuk menikah,seseorang diperbolehkan untuk menikah jika sudah dewasa (baligh) memiliki kemampuan bertindak hukum secara sempurna (ahliyyah alada'al-kamilah). ${ }^{22}$

Batas umur melakukan perkawinan menurut kompilasi hukum islam Pada pasal 15 ayat (1), yaitu: "untuk kemashlahatan keluarga dan rumah tangga, perkwinan hanya boleh dilakukan calon mempelai yang telah mencapai umur yang ditetapkan dalam pasal 7 undang-undang nomor 1 tahun 1974 yakni calon suami berumur sekurangkurangnya berumur 19 tahun dan calon isteri sekurang-kurangnya 16 tahun." Dan pada ayat (2), "bagi calon mempelai yang belum berumur 21 tahun harus mendapati izin yang sebagaimana yang diatur dalam pasal 6 ayat (2), (3), (4), dan (5) undang-undang nomor 1 tahun 1974 tentang perkawinan."47 c. Batas umur melakukan perkawinan menurut undang-undang nomor 1 tahun 1974 tentang perkawinan Dalam BAB II syarat-syarat perkawinan pasal 6 ayat (2), yaitu : "untuk melangsungkan perkawinan seorang yang belum mencapai umur 21 tahun harus mendapat izin kedua orang tua." 23

Sedangkan pada pasal 7 ayat (1) undang-undang perkawinan : "perkawinan hanya diizinkan jika pria sudah mencapai umur 19 tahun dan pihak wanitasudah mencapai umur 16 tahun. Dan pada ayat (2) "dalam hal penyimpangan terhadap ayat (1) pasal ini dapat meminta dispensasi nkah kepada penngadilan agama atau penjabat lain yang ditunjuk oleh kedua orang tua pihak pria maupun wanita. Dan ayat (3) "ketentuan-ketentuan menganai keadaan salah seorang atau kedua oaring tua tersebut dalam pasal 6 ayat (3) dan (4) undang-undang ini. Berlaku juga dalam hal permintaan dispensasi tersebut ayat (2) pasal ini dengan tidak mengurangi yang dimaksud dalam psal 6 ayat $(6) .^{24}$

\section{Batasan umum melakukan perkawinan menurut Undang-Undang Hukum Perdata (KUHPER)}

Ada beberapa hal yang mendorong terjadinya pernikahan di bawah umur terutama diwilayah pedesaan. Adapun hal-hal pendorong tersebut, diantaranya :

a. Faktor perkawinan atas kehendak orang tua Masyarakat pedesaan pada umumnya tidak menganggap perkawinan dini/atau perkawinan di bawah umur tidak akan mempengaruhi kehidupan rumah tangga mereka pada nantinya. Orang tua di pedesaan pada umumnya hanya menilai bahwa seorang wanita yang sudah baligh (dalam agama islam baligh bagi anak perempuan ditandai dengan mestruasi) dan bagi anak laki-laki ditandai dengan "mimpi basah" (baligh) dan/atau sudah bekerja. Apabila sudah memenuhi kriteria tersebut para orang tua segera mencarikan jodoh untuk anak mereka. ${ }^{25}$

\footnotetext{
${ }^{22}$ Ibid,hlm 82

${ }^{23}$ Aisyah Dachlan, Membina Rumah Tangga Bahagia dan Peran Agama dalam Rumah Tangga, Jamunu, Jakarta, 2010, hlm.81.

${ }^{24}$ Nuansa Aulia, Kompilasi Hukum Islam : Hukum Perkawinan, Hukum Kewarisan, dan Hukum Perwakafan, cet.II, Bandung : Tim Redaksi Nuansa Aulia,hlm 5

${ }^{25}$ Yahya Harahap, Hukum Perkawinan Indonesia, Medan, Cv Zahir Tranding Co. 2007, hlm.71.
} 
b. Kemauan dari sang anak Banyak anak yang melangsungkan perkawinan pada usia belia karena kemauan mereka sendiri, itu semua didasari oleh pergaulan dari lingkungan yang sangan rendah pengetahuannya. Disinilah peran orang tua sangat dibutuhkan untuk memberikan pengetahuan yang baik untuk sang anak. ${ }^{26}$

c. Pengaruh Adat dan Budaya Sudah menjadi kebiasaan dan sudah sejak dahulu masyarakat pedesaan dianggap dan dipandang kolot, karena apabila ada anak perempuan yang sudah mengalami akil baligh (mestruasi) tidak segera di jodohkan dengan seorang laki-laki yang sudah akil baligh (mimpi basah) juga, mereka akan di sebut dengan sebutan "perawan tua" atau "bujang lapuk". Sehingga untuk menutupi rasa malu tersebut maka orang tua mengawinkan anaknya meskipun masih sangat kecil. ${ }^{27}$

d. Pengaruh Rendahnya Pendidikan Rendahnya tingkat pendidikan orang tua dan masyarakat membuat perkawinan dini semakin marak, sehingga kebiasaan ataupun adat yang kurang patut dan masih berkembang di masyarakat akan sulit untuk dihilangkan. ${ }^{28}$

e. Faktor Ekonomi Faktor ini merupakan salah satu faktor yang menjadikan manusia merasa bahagia dan berkecukupan. Tujuan orang tua menikahkan anaknya adalah agar orang tua segera bebas dari tanggungjawabnya sebagai orang tua. Selain itu juga dapat menambah keluarga dan bertambahnya keluarga tersebut dipercayai akan menambah Rizky pula. ${ }^{29}$

f. Faktor MBA (Married by Accident) Faktor ini tidak hanya marak atau terjadi di pedesaan saja melainkan di perkotaan juga sudah banyak sekali para remaja yang salah untuk bergaul. Selain faktor pergaulan bebas terdapat beberapa faktor penyebab terjadinya Married by Accident tersebut, diantaranya adalah :

1. Mudahnya pengaksesan hal-hal yang berbau pornogafi maupun pornoaksi

2. Pergaulan bebas ;

3. . Kurangnya pengawasan orang tua; dan

4. Lemahnya pemahaman tentang agama. ${ }^{30}$

\section{Dampak dari Perkawinan di Bawah Umur}

Perkawinan anak di bawah umur merupakan hal yang di anggap tidak patut oleh masyarakat modern seperti saat ini, karena perkawinan anak di bawah umur memiliki dampak yang sangat buruk dan perkawinan tersebut tidak akan berjalan dengan semestinya. Beberapa penelitian menyimpulkan bahwa perkawinan di bawah umur memiliki dampak, diantaranya :

\section{Dampak Biologis}

Secara Biologis alat-alat reproduksi anak masih dalam proses menuju kematangan sehingga belum siap untuk melakukan suatu hubungan intim atau melakukan seks dengan pasangannya, bahkan rentan terhadap gangguan kesehatan reproduksi, seperti kanker serviks dan penyakit seksual yang menular. Jika dipaksakan akan

\footnotetext{
${ }^{26} \mathrm{Ibid}, \mathrm{hlm} 83$

${ }^{27}$ Loc, cit. Nuansa Aulia, hlm 43

${ }^{28}$ Loc, cit. Yahya Harahap, hlm 23

${ }^{29}$ Ibid, hlm 27
}

30 Wida " Sulistya, Married B Bccident “, (https://remajamasakini.com.wordpress.caccidentmba-2/html=m?), diakses 25 Februari 2021.Pukul $13.50 \mathrm{Wib}$ 
sangat beresiko terhadap bahaya pendarahan dan kerusakan organ yang dapat mengakibatkan kematian. ${ }^{31}$

2. Dampak Psikologis

Secara psikis anak belum siap dan memahami tentang hubungan seks, sehingga akan menimbulkan trauma yang berkepanjangan dan akan sangat sulit di sembuhkan. Anak akan lebih cenderung menyendiri, dan menyesali kehidupannya. Selain itu, ikatan perkawinan akan menghilangkan hak anak untuk memperoleh pendidikan, hak untuk bermain, dan menikmati masa kecilnya dengan teman-teman sebayanya.

\section{Dampak Sosial}

Perkawinan anak di usia muda berinfestasi pada masalah sosial yang lebih kompleks di masa mendatang. Ketidaksiapan mental anak, sosial dan ekonomi anak untuk berumah tangga dapat mengakibatkan terjadinya kekerasan dalam rumah tangga. Banyaknya anak yang terlantar dan terabaikan, atau masalah status dan kesehatan ibu dan anak. Banyak anak yang lahir menyandang masalah kesehatan, pengangguran dan lainnya akibat perkawinan di bawah umur tersebut. Selain itu akan terjadi perilaku yang menyimpang apabila seorang anak tidak cukup paham mengenai perkawinan. $^{32}$

\section{KESIMPULAN}

Perkawinan anak di bawah umur merupaka suatu fenomena sosial yang kerap terjadi, khususnya di Indonesia. Fenomena perkawinan anak di bawah umur, apabila di ibaratkan akan menjadi seperti fenomena gunung es, sedikit dipermukaan atau yang terekspos dan sangat marak di dasar atau di tengah masyarakat luas. Pemerintah harus sangat berkomitmen serius dalam menegakakan hukum yang berlaku mengenai perkawinan di bawah umur, sehingga pihak-pihak yang ingin melakukannya dapat berfikir dua kali apabila ingin melakukan hal tersebut. Selain itu Pemerintah harus semakin mensosialisasikan Undang-undang terkait beserta sanksi-sanksi apabila ada masyarakat yang melanggarnya.

\section{SARAN}

Diharapkan dengan upaya tersebut, masyarakat tahu, memahami dan sadar bahwa perkawinan di bawah umur adalah sesuatu yang salah dan harus di hindari. Akan lebih maksimal pula apabila masyarakat juga ikut berperan aktif dalam pencegahan pernikahan anak di bawah umur yang ada di lingkungan sekitar. Agar kedepannya tidak akan ada lagi anak yang menjadi korban akibat pernikahan tersebut, dan anak Indonesia dapat lebih optimis dalam menatap masa depannya kelak.

${ }^{31}$ rfan Muliawan, "Pengaruh Perkawinan Usia Muda Terhadap Tingginya Tingkat Perceraian Di Pengadilan Agama Pontianak”, Jurnal Gloria Yuris Prodi Ilmu Hukum 1, NO. 2 (2013), http://junal.untan.ac.id/index.php/jmfh/article/view/2142. Di akses 24 Februari 2021 Pukul 16.40 Wib

${ }^{32}$ Ibid, Rfan Muliawan 


\section{DAFTAR PUSTAKA}

\section{A. Buku-Buku}

Agus Riyadi, Bimbingan Konseling Perkawinan, (Yogyakarta: Ombak, 2013).

Ashad Kusuma Djaya. "Rekayasa Sosial Lewat Malam Pertama: Pesan- Pesan Rasulullah SAW Menuju Pernikahan Barakah”. (Yogyakarta : Kreasi Wacana 2000).

Astrina Primadewi Yuwono, "Perlindungan Hukum Bagi Anak Terhadap Perkawinan Di Bawah Umur", Tesis, (Program Pascasarjana Universitas Indonesia, Jakarta, 2008).

Departemen Pendidikan Nasional Kamus Besar Bahasa Indonesia, (Jakarta: Gramedia Pustaka Utama, 2008).

Fauziatu Shufiyah, "Pernikahan Dini Menurut dan Dampaknya", Jurnal Living Hadis, (Volume 3, Nomor 1, Mei 2018).

Hendra Akhdhiat, Psikologi Hukum, (Bandung: Pustaka Setia, 2011).

Hilman Hadikusuma, Hukum Perkawinan Indonesia (Bandung: Mandar Maju, 2007).

J. Moleong, Metodologi Penelitian Kualitatif, (bandung: Remaja Rrosdakarya, 2008).

M. Yahya Harahap. Beberapa Tinjauan Mengenai Sistem Peradilan dan Penyelesaian Sengketa. (Bandung: Citra Aditya Bakri, 1997).

Mukti Fajar dan Yulianto Achmad, 2010, Dualisme Penelitian Hukum Normatif dan Empiris, Pustaka Pelajar, Yogyakarta).

Maidin Gultom, Perlindungan Hukum Terhadap Anak dan Perempuan. Bandung: PT. Refika Aditama).

Sugiyono, Metode Penelitian penelitian kuantitatif, kualitatif, dan R\&D, (Bandung: Alfabeta, Cet-17,2012).

Suharsimi Arikunto,Managenen Penelitian, (Jakarta:PT Asdi Mahsatya, 2013).

Wagiati Sutedjo, Hukum Pidana Anak, (PT Refika Aditama, Bandung : 2010).

Zahara Tussoleha Rony,’SIAP FOKUS, SIAP MENULIS”(Jakarta:PSSDM).

\section{B. Perundang-Undangan}

Undang-Undang Nomor 16 Tahun 2019 Tentang Perkawinan Pasal 7 Ayat 1

Undang-Undang Nomor 16 Tahun 2019 Perubahan Atas Undang-Undang Nomor 1 Tahun 1974 tentang Perkawinan Pasal 1.

UU No.1 Tahun 1974 Tentang Perkawinan

Pasal 1 angka 2 Undang-Undang Nomor 23 Tahun 2002 Tentang Perlindungan Anak.

Pasal 4 Undang-Undang Nomor 23 Tahun 2002 Tentang Perlindungan Anak.

Pasal 78 Undang-Undang Nomor 23 Tahun 2002 Tentang Perlindungan Anak

Pasal 88 Undang-Undang Nomor 23 Tahun 2002 Tentang Perlindungan Anak. 
Pasal 82 Undang-Undang Nomor 23 Tahun 2002 Tentang Perlindungan Anak.

\section{Artikel, Jurnal}

Fauziatu Shufiyah, "Pernikahan Dini Menurut dan Dampaknya", Jurnal Living Hadis, Volume 3, Nomor 1, Mei 2018, h. 63.

Eleanora, F. N., \& Dwi Atmoko. (2021). Aktualisasi Sertifikasi Pranikah Dalam Meminimalisir Kekerasan Dalam Rumah Tangga. Jurnal Hukum Sasana, 7(1). https://doi.org/10.31599/sasana.v7i1.477

Masri, E. (2019). Poligami Dalam Perspektif Undang-Undang Nomor I Tahun 1974 Tentang Perkawinan Dan Kompilasi Hukum Islam (KHI). Krtha Bhayangkara, 13(2). https://doi.org/10.31599/krtha.v13i2.7

Muhammad Faisal Hendriawan, Putri, E. A., \& Otih Handayani. (2020). Analisis Legal Standing Penerbitan Surat Keterangan Nikah oleh Kepala Desa Pada Pernikahan Siri di Desa Banjarsari Bekasi. KRTHA BHAYANGKARA, 14(2). https://doi.org/10.31599/krtha.v14i2.389

Teguh SuryaPutra, "Dispensasi Umur Perkawinan (Studi Implementasi Pasal 7 Ayat 2 Undang-Undang Nomor 1 Tahun 1974 Di Pengadilan Agama Kota Malang)," Artikel Ilmiah, dipresentasikan untuk memenuhi sebagian syarat-syarat untuk memperoleh gelar kesarjanaan dalam ilmu hukum pada tahun 2013).

Rahmatiah H1, "Studi Kasus Perkawinan Dibawah Umur", Dalam Jurnal Al daulah, volume 5, Nomor 1, Juni 2016).

Rohman. Adi Nur (2020). Upaya Memantapkan Peraturan Isbat Nikah Dalam Hukum Perkawinan Di Indonesia. Jurnal Hukum Sasana, 6(1). https://doi.org/10.31599/sasana.v6i1.173

Eka Rini Setiawati, "Pengaruh apernikahan Dini Terhadap Keharmonisan Pasangan Suami Dan Istri Di Desa Bagan Bhakti Kecamatan Balai Jaya Kabupaten Rokan Hilir", Dalam Jurnal Jom FISIP Volume 4 No 1 Februari 2017).

\section{Sumber Lain}

Putusan Mahkamah Konstitusi Nomor: 30-74/PUU-XII/2014 
Available online at: http://ejurnal.ubharajaya.ac.id/index.php/sasana 